\title{
PRODUCTION AND USE OF A SHELF-STABLE BOVINE BLOOD POWDER FOR FOOD FORTIFICATION AS A FOOD-BASED STRATEGY TO COMBAT IRON DEFICIENCY ANAEMIA IN SUB- SAHARAN AFRICA
}

Kikafunda $J K^{I^{*}}$ and Sserumaga $P^{l}$

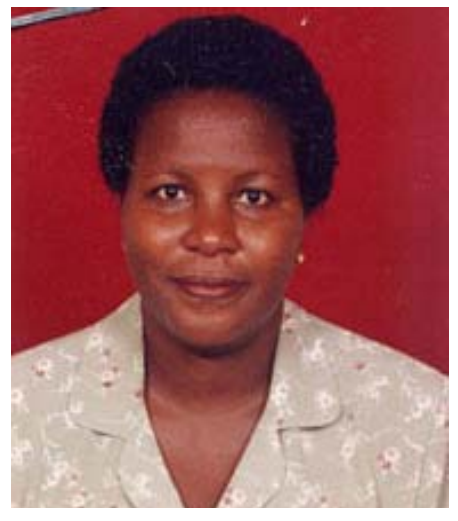

JOYCE KIKAFUNDA

* Correspondence Author - Dr. Joyce K. Kikafunda (PhD) Senior Lecturer, Department of Food Science and Technology, Makerere University. P. O. Box 7062, Kampala, Uganda Tel: 256-41-533 676; Fax: 256-41-531 641. E-mail; joycek@agric.mak.ac.ug ${ }^{1}$ Department of Food Science and Technology, Makerere University, P.O. Box 7062, Kampala, Uganda 


\section{ABSTRACT}

Iron deficiency anaemia (IDA) is the most widespread micro-nutrient deficiency disease world-wide, particularly in developing countries. Although there are several strategies to combat IDA, food-based strategies are the most sustainable and yet little research has been carried out in this area. The study aimed at developing a technology for processing and preserving bovine blood into a shelf-stable powder, which would easily be utilised in fortifying commonly consumed food items, as a food-based strategy in the fight against iron deficiency anaemia. A shelf-stable powder was processed from fresh bovine blood and the physical, chemical, microbiological and shelf-life characteristics assessed using conventional methods. The results of the chemical analysis showed that bovine blood powder has a very high concentration of haeme iron at $195.46 \mathrm{mg} / 100 \mathrm{~g}$ of powder. This is more than ten times the level of iron in bovine liver, one of the most commonly used food source of haeme iron whose iron content is only $17 \mathrm{mg} / 100 \mathrm{gm}$ of liver. Although microbiological tests carried out on the freshly processed blood powder and on the same powder after one and three months of storage at room temperature found a significant rise in yeast, mould and total plate counts, these values were low and within safe limits. The blood powder was used to fortify a bean sauce. Sensory analysis panellists considered the fortified bean sauce moderately acceptable with a mean score of 4.667 (like slightly) compared to a mean score of 2.333 (like very much) for the non-fortified sauce, on a nine point Hedonic scale. These findings show that processed bovine blood powder has very high levels of haeme iron and thus has great potential as a food-based strategy to combat iron-deficiency anaemia in resource-poor developing countries, particularly those in sub-Saharan Africa. However, more research is needed to improve the microbiological and sensory characteristics of the blood powder.

Key Words: Bovine blood, Iron deficiency anaemia, Sub-saharan Africa

\section{FRENCH}

\section{RÉSUMÉ}

L'anémie due à la carence en fer (ACF) est la maladie la plus répandue dans le monde comme conséquence de la carence en micronutriments, particulièrement dans les pays en développement. Bien qu'il existe de nombreuses stratégies pour combattre l'ACF, des stratégies basées sur l'alimentation sont les plus viables; cependant, très peu de recherches ont été menées dans ce domaine. La présente étude avait pour but de mettre au point une technologie qui consiste à traiter et conserver du sang de bovin dans une poudre, qui serait facilement utilisé en fortifiant des denrées alimentaires communément consommées, comme une stratégie basée sur l'alimentation dans la lutte contre l'anémie causée par la carence en fer. Ce genre de poudre a été traitée à partir de sang de bovin frais et les caractéristiques physiques, chimiques, microbiologiques et de durée de conservation ont été évaluées en utilisant des méthodes conventionnelles. Les résultats de l'analyse chimique ont montré que la poudre de sang de bovin a une très haute concentration de fer à 195.46 
mg/100g de poudre. Cette concentration est plus de dix fois la teneur en fer dans le foie de bovin, l'une des sources alimentaires de fer les plus couramment utilisées dont la teneur en fer n'est que $17 \mathrm{mg} / 100 \mathrm{gm}$ de foie. Bien que des tests microbiologiques effectués sur la poudre de sang fraîchement traité et sur la même poudre après un et trois mois de conservation à la température ambiante aient indiqué une importante augmentation dans les taux de levure, du mole et de la plaque totale, ces valeurs étaient basses et dans des limites sûres. La poudre de sang a été utilisée pour fortifier une sauce de haricots. Des parallélistes d'analyse sensorielle ont considéré la sauce de haricots fortifiée comme étant modérément acceptable avec un score moyen de 4.667 (légèrement par rapport à un score moyen de 2.333 (beaucoup) pour la sauce non fortifiée, sur une échelle hédonique de neuf points. Ces résultats montrent que la poudre de sang de bovin traitée a des niveaux très élevés de fer et que, par conséquent, cette poudre est certainement bien indiquée pour servir de stratégie basée sur l'alimentation permettant de combattre l'anémie causée par la carence en fer dans des pays en développement ayant des ressources maigres, particulièrement ceux de l'Afrique subsaharienne. Néanmoins, il faudrait mener davantage de recherches pour améliorer les caractéristiques microbiologiques et sensorielles de la poudre de sang

Mots-clés: Sang de bovin, anémie causée par la carence de fer, Afrique subsaharienne.

\section{INTRODUCTION}

Iron deficiency anaemia (IDA) is the most prevalent micro-nutrient deficiency disease worldwide, particularly in developing countries with Asia and sub-Sahara Africa taking the bulk of the problem [1-4]. In some countries in Sub-saharan Africa, it is estimated that over $80 \%$ of women, infants and young children are affected by anaemia [4]. Most of the anaemia is due to iron deficiency. IDA results from persistent consumption of monotonous, plant-based, low-iron diets with poor bio-availability. [2-5]. IDA is also exacerbated by high prevalence of malaria and hookworm infestation, both endemic in many developing countries. IDA results in pregnancy waste, increased risk of maternal mortality, intra-uterine growth retardation, low birth weights, retarded growth, impaired cognitive development, diminished learning capacity, fatigue and reduced work capacity and output [1-6].

The prevalence of IDA in Uganda, especially among the vulnerable groups of pre-school age children, pregnant and lactating mothers, adolescent girls and women of child bearing ages, is postulated to be very high although national data is scarce [7] The recent Uganda

Demographic and Health Survey report revealed that nation-wide, 64\% of children under five years of age and $30 \%$ women in the reproductive age range are anaemic [8].

Blood is the transport medium in animal systems by which cells exchange materials such as gases, nutrients and wastes. The red blood cells, a main component of blood, contain haemoglobin whose major function is transport of oxygen within the body. The functional 
element of haemoglobin is haeme iron. Over $60 \%$ of the body's iron is found in haemoglobin. Blood has the largest concentration of haeme iron compared to any other animal sources $[9,10]$.

Many communities in Africa, particularly the cattle keepers such as the Hima, Karamajong and Masai, do process and consume blood collected during slaughter. However, the processing, hygiene and safety of this blood meal is not ascertained. On the other hand, the Moslem communities, who actually do most of the slaughter in many countries, by their Islamic laws, condemn the consumption of blood [11]. This is probably one of the reasons why blood consumption by humans has been very low world-wide. After slaughter, most of the blood goes to waste and only a small amount goes into the human food chain.

There are several strategies aimed at combating micro-nutrient malnutrition such as supplementation with capsules and tablets and fortification of industry processed foods. However, food-based strategies are the most sustainable in resource poor developing countries $[1,3,12]$. Although progress has been made in vitamin A and iodine deficiency control programmes, little progress has been made in IDA control programmes [4,5]. Little research has been done in the area of food-based interventions for reduction of micronutrient malnutrition in general and even less research for iron deficiency anaemia. This study aimed at developing a process whereby bovine blood could be collected, processed and preserved into a shelf-stable powder which can then be used to fortify a commonly consumed sauce. Bean sauce was selected because beans are one of the most commonly consumed foods in subSaharan Africa. The physical, chemical, microbiological and shelf life characteristics of the preserved powder and the sensory attributes of the fortified sauce were determined. 


\section{MATERIALS AND METHODS}

\section{Processing of the bovine blood powder}

Fresh bovine blood was collected from abattoirs in Kampala City, Uganda. Two litres of fresh blood were collected from each animal, straight from the jugular vein just as soon as it was cut during the process of slaughter. At this point, blood was still liquid and warm. Lemon juice, an anti-coagulant, was added to the blood to keep it liquid during transportation from the abattoir to the Food Science and Technology laboratory, at Makerere University.

In the laboratory, the blood was poured into double 250 gauge polythene bags and tied at the top. The packaged blood was then pasteurised in a hot water bath for 45 minutes (timing commenced when boiling started) at approximately $100{ }^{\circ} \mathrm{C}$. The resulting blood cakes were broken into small pieces by use of a pastry stick to ease drying. The wet blood crumps were spread on an oven tray dressed in aluminium foil and dried overnight in an oven at relatively low temperatures $\left(55-60{ }^{\circ} \mathrm{C}\right)$ to minimise the level of protein denaturation. After drying, the flakes were crushed into a powder using an electric blender and sieved through a 250 micrometer sieve. The freshly processed blood powder was assessed for physical, chemical, and microbiological characteristics. Samples of the processed blood powder were packaged into 250-gauge polythene bags, sealed and stored at room temperature for three months and further assessment carried out on the stored product.

\section{Physical properties of the bovine blood powder}

The yield of the blood powder was determined by measuring the blood volumes using a one litre measuring cylinder and weighing the powder obtained after drying using an analytical balance (Sartorius BA 21005, Germany). Re-hydration ratio and solubility in hot water of the blood powder were measured by pouring boiling distilled water into a beaker containing the blood powder ( $200 \mathrm{ml}$ of boiling water per $20 \mathrm{gms}$ of blood powder). The mixture was left to stand for 30 minutes with intermittent stirring after which the water was filtered off and the weight of the soaked powder and water absorbed determined. An aliquot of $25 \mathrm{ml}$ of drain water was transferred to a petri dish and evaporated to dryness using a water bath followed by an air oven dryer at $60{ }^{\circ} \mathrm{C}$ until a constant weight was recorded. The weight of the recovered solids was used to calculate the solubility of the powder components. For the solubility in salt solution, $1 \%$ salt was added to the water and the determination carried out as described for water solubility.

The colour of the blood powder was determined using a Lovibond Tintometer, mode E AF 900 (The Tintometer Limited, Salisbury, UK). Colour matches were made between the powder and the Lovibond's blue, yellow and red spectra for the most perfect matches and readings recorded. 


\section{Chemical Properties of the bovine blood powder}

Moisture content, crude protein and ash content of the blood powder were determined using standard procedures [13]. Iron content was determined by colorimetric methods, using an SP 600 Spectrophotometer (Pye Unicam Ltd. York Street, Cambridge, UK) at 520 nanometer wavelength. Calcium, magnesium and phosphorous were determined using a Perkin-Elmer 2380 Atomic Absorption Spectrophotometer (U.S. Instrument division, Norwalk, CT.) on digest of blood powder done by wet ashing using a digestion mixture containing selenium powder, lithium sulphate, hydrogen peroxide and concentrated sulphuric acid. The specific wavelengths used for the minerals were $422.7 \mathrm{~nm}$ for calcium, $285.2 \mathrm{~nm}$ for magnesium and $213.6 \mathrm{~nm}$ for phosphorus. The manufacturers' instructions for both Unicam and Atomic Absorption Spectrophotometers were observed.

\section{Microbial Tests}

Microbial load of the blood powder was determined on freshly processed blood powder and after one month and three months of storage at room temperature. Total aerobic counts were determined using plate count agar [14] and yeasts and mould counts were determined using Potato dextrose agar [15]. The analysis was done in triplicate.

\section{Preparation of the bean sauce}

Beans (Phaseolus vulgaris L.) were chosen as the fortification vehicle for this study because beans are the most widely consumed legumes world-wide but particularly in low income economies like Uganda. In Uganda, beans are the most widely consumed food stuffs by all categories of people; young and old, both the rich and the poor. The traditional method of preparing bean sauce in Uganda was used. Five hundred grams $(500 \mathrm{~g})$ of dry red kidney beans were boiled for two and a half hours until soft. They were then shallow fried with cooking oil and tomatoes. Salt and curry powder were added to taste. One heaped table spoon-full (about $15 \mathrm{~g}$ ) of freshly processed blood powder was sprinkled into the bean sauce, just as one would add curry powder. The sauce was then simmered for a further 20 minutes. Another sauce was prepared in a similar way but with no added blood powder, to act as a control. 


\section{Sensory Analysis}

Sensory analysis was carried out on the two bean sauces (fortified and non-fortified) using standard sensory analysis procedures [16]. The two sauces were served when hot to an untrained panel of 19 people comprised of students and staff of Makerere University, after obtaining their consent. The panellists were requested to assess 3 parameters; colour, flavour and overall acceptability. A nine point Hedonic scale was used ranging from 1 (like extremely) through 5 (neither like nor dislike) to 9 (dislike extremely) [16].

\section{Ethical Considerations}

Since human subjects were used in the sensory analysis, ethical clearance was sought and obtained from Uganda National Council of Science and Technology. Individual consent was also obtained from the panellists before their participation in the study.

\section{Statistical Analysis}

The data for the microbiological and sensory analysis was analysed using the Statistical Package for Social Scientists (SPSS, version 10). Analysis of variance (ANOVA) was used to assess statistical significance between the different parameters in the microbiological and sensory analyses using the Least Significance Difference (LSD) method. Significance was set at $\mathrm{P}<0.05$. 


\section{RESULTS}

Physical properties of processed bovine blood powder

The average yield of bovine blood powder (wt/vol) was $209.05 \pm 20.3 \mathrm{gm} /$ litre of fresh blood. The average dry matter and moisture contents of the blood powder were found to be $93.15 \pm 2.53 \%$ and $6.85 \pm 1.51 \%$, respectively. The re-hydration ratio of the blood powder was found to be $3.237 \mathrm{~g}$ of water per gram of powder. In a $1 \%$ salt solution, the re-hydration ratio was found to be only $2.903 \mathrm{~g}$ of solution per gram of powder. Results obtained showed that, about twice the amount of solubles were released in a $1 \%$ salt solution $(0.1263 \mathrm{~g}$ per gram) compared to that in water alone $(0.0581 \mathrm{~g}$ per gram).

For all the primary colours, blood powder treated with citric acid had lower intensity than that of powder that was not treated with citric acid. Treatment of blood with citric acid lowered its ability to decolourise the sauce.

\section{Chemical properties of processed bovine blood powder}

The chemical composition of the blood powder is shown in table 1 . The ash and crude protein contents of the blood powder were found to be $4.13 \pm 0.66 \%$ and $79.18 \pm 1.86 \%$, respectively. The concentration of iron was found to be $195.46 \pm 19.84 \mathrm{mg} / 100 \mathrm{~g}$. The Calcium, magnesium and phosphorus contents of the blood powder were found to be $10.24 \pm 4.41,16.50 \pm 3.65$ and $130.00 \pm 45.21, \mathrm{mg} / 100 \mathrm{~g}$, respectively. 


\section{Microbiological studies}

The results of the microbial studies done on the freshly processed blood samples and those stored for one and three months at room temperature are shown in table 2 . The yeast and mould counts of the blood powder significantly $(p<0.05)$ increased over time. The total viable counts also significantly $(\mathrm{p}<0.05)$ increased with increasing time of storage.

\section{Sensory evaluation}

The results of the sensory analysis are shown in table 3 . The colour of fortified and nonfortified sauces differed significantly $(p<0.05)$. The blood powder darkened the bean sauce and the panellists gave a moderate score of 5.367 (neither like nor dislike) to the fortified sauce compared to a score of 2.10 (like very much) for the non fortified sauce. The flavour of the two sauces was also significantly $(\mathrm{p}<0.05)$ different with a score of 3.30 (like moderately) for the fortified sauce and 2.533 (like very much) for non-fortified sauce. The over-all acceptability of the two sauces was also significantly $(\mathrm{p}<0.05)$ different, with the fortified sauce having a score of 4.667 (like slightly) while the none fortified bean sauce scored 2.333 (like very much).

\section{DISCUSSION}

\section{Physical and chemical characteristics of the processed bovine blood powder}

Results obtained from the solubility studies showed that about twice the amount of solubles were released in a $1 \%$ salt solution compared to that in un-salted water. The low solubility was probably because heating introduces gel bonds into the proteins of the blood, which lead to a high level of hydrophobicity hence water cannot get in and out of the interior of the particles to dissolve the solubles there [17]. In addition, at a higher ionic strength of the cooking medium, cook loss of the food into the medium is elevated. Amino acids in their raw state show a good level of solubility in warm water (about $25^{\circ} \mathrm{C}$ ). On heating, globular proteins form irreversible heat-setting gels, which are more hydrophobic than the raw proteins [17]. This might have been the cause of the low rehydration of the blood powder. Overall, it was favourable that solubility was higher in a salt solution than in bare water as salt is usually added to sauces.

The average ash content of $4.13 \pm 0.66 \%$ was similar to that of $4.45 \%$ reported by Pomeranz and Clifton [18]. The crude protein content of the blood powder at $79.18 \pm 1.86 \%$ is slightly lower than the value of $84 \%$ reported again by Pomeranz and Clifton [18]. Nutritional factors, level of feed intake and other factors such as age, sex and genetic background have been shown to cause differences in protein content in animals products [19].

The concentration of iron in the processed blood powder was found to be very high at 195.46 $\mathrm{mg} / 100 \mathrm{~g}$ of powder. Comparing with the values of iron from other iron rich foods in Food Composition Tables [20], it was found that the bovine blood powder had a much higher iron content compared to other known food sources of iron (table 4). The $15 \mathrm{~g}$ of powder added to 
the bean sauce would satisfy the daily iron requirements of two adults at a requirement of 15 $\mathrm{mg}$ of iron per day [21]. The levels of the other minerals (calcium, magnesium and phosphorus) were comparable with values reported in the literature [18]. Like protein content, mineral composition of the whole body will vary with age, fatness, and to some extent to the species of the animal [19]. 


\section{Microbiological issues and Sensory characteristics}

Although the microbial studies showed a significant increase in the yeast, mould and total plate counts of the blood powder within 3 months of storage, the values were low and within safe levels. FAO/WHO set safe levels for yeasts and moulds in food materials at not more than $10^{4} \mathrm{cfu} / \mathrm{g}$ and a range of 100-100,000 cfu/g for total plate counts [22]. Although the values are low, still more caution during the preparation and storage is required as the counts might rise to levels that might cause harm. More research is required in the area of post production storage conditions, particularly temperature, humidity and duration of storage.

The fortified sauce was moderately accepted with an overall acceptability score of 4.667 (like slightly) compared to a score of 2.333 (like very much) for the non-fortified sauce. Sensory attributes play an important role in food acceptance and rejection, irrespective of the nutritional content of the food [16]. It is therefore worth noting that although the fortified sauce was not highly liked, it was not out-right rejected. The texture of the fortified sauce was rubbery because the particles in the blood powder imbibed water and obtained an inflated, rubbery texture. This is due to the high proteinecious nature of the blood, which on heating allows formation of gel bonds including disulphide linkages, salt bridges and hydrophobic bonds [17]. This lowered the rheological quality of the sauce, making it more chewee.

Iron fortification is the optimal approach for reducing iron deficiency anaemia in developing countries [4,5]. However, several factors such as the nature of the diet, level of food industrialisation and cost make it difficult for this approach to be utilised on a widespread scale in many developing countries. Use of haemoglobin in the form of dried blood cells or as a powder as was done in the present study, comes as a practical option to the above problems of elemental iron fortification. In addition, the haeme iron is easily absorbed as it is resistant to iron inhibitors such as phytates [5,23], which are common in the predominantly plant-based diets in sub-Saharan Africa.

Longitudinal studies in developing countries have demonstrated a reduction in the prevalence of anaemia in children fed on haemoglobin fortified foods. Studies in Chile found a reduction in the prevalence of anaemia in school children (10-16 years of age) after 3 years of feeding on a $6 \%$ haemoglobin fortified biscuit [24]. In an earlier study, infants (4-12 months of age) fed on a $5 \%$ haemoglobin fortified extruded rice for 12 months had improved iron status compared to the control group fed on regular infant foods [25].

The main limitations with use of bovine blood is the difficulties in collecting the blood, especially in countries where culture or religion forbid use of blood as food. Also, the intense red-brown colour put off some consumers. This colour problem can be reduced by adding the powder to sauces that are naturally dark in colour or adding the powder by sprinkling thus facilitating use of low levels of the powder.

In order to have a well processed and safe blood powder, the following are recommended: 
- Only blood from animals that have been certified by a Veterinary Doctor as safe for human consumption should be used to avoid problems of unsafe raw materials. Blood is a highly proteinecious product and therefore highly susceptible to microbial contamination. It should thus be collected with the highest degree of hygiene and sanitation to minimize microbial contamination.

- Processing of the collected blood should start as soon as possible to ensure that the processing starts with a low level of microbial count.

- The recommended conditions of temperature and time during processing should be strictly followed to allow maximum destruction of micro organisms in the blood at the same time, avoiding excessive coagulation of the proteins which not only reduce nutritional value but also result in altered texture.

- Drying of the blood cake should be done to as low moisture content as possible to minimize the microbial proliferation.

- Handling of the blood powder should be done in a hygienic way to avoid recontamination of the powder with yeasts and moulds, which are known to be ubiquitous.

- Citric acid, in the form of lemon juice, should be added to the liquid bovine blood just after collecting to prevent coagulation, improve on the efficiency of pasteurisation and also lower the colour intensity of the resultant powder. Extra care is particularly needed in warm, moist tropical environments which are the normal climates of most countries in the sub-Saharan Africa.

\section{CONCLUSION}

In conclusion, the findings of this study show that processed bovine blood powder has high concentrations of haeme iron and when the powder is used to fortify a commonly consumed sauce such as bean sauce, it is moderately accepted. The powder can be sprinkled into the sauce in the final stages of the cooking process, the amount depending on taste preferences, just as is done for curry powder. Processed bovine blood powder hence has great potential as a food-based strategy to combat iron deficiency anaemia in low income households where no cultural or religious barriers prevent its consumption. However, more research work is needed to improve the microbiological and sensory attributes of the processed blood powder. 


\section{TABLES}

\section{Table 1}

Chemical Composition of the blood powder*

\begin{tabular}{ll}
\hline Component & Concentration \\
\hline Moisture $(\%)$ & $6.85 \pm 1.51$ \\
Ash $(\%)$ & $4.13 \pm 0.66$ \\
Crude protein $(\%)$ & $79.18 \pm 1.86$ \\
Iron $(\mathrm{mg} / 100 \mathrm{~g})$ & $195.46 \pm 19.84$ \\
Calcium $(\mathrm{mg} / 100 \mathrm{~g})$ & $10.24 \pm 4.41$ \\
Magnesium $(\mathrm{mg} / 100 \mathrm{~g})$ & $16.50 \pm 3.65$ \\
Phosphorus $(\mathrm{mg} / 100 \mathrm{~g})$ & $130.00 \pm 45.21$ \\
\hline
\end{tabular}

* Each figure is a mean of 3 samples 


\section{Table 2}

Yeasts, moulds and total plate counts during storage

\begin{tabular}{lll}
\hline Time of storage & $\begin{array}{l}\text { Total Plate Counts* } \\
(\log 10 \text { of the counts })\end{array}$ & $\begin{array}{l}\text { Yeast and Mould Counts* } \\
(\log 10 \text { of the counts })\end{array}$ \\
\hline 0 Months & $3.126^{\mathrm{a}}$ & $2.248^{\mathrm{a}}$ \\
1 Month & $3.467^{\mathrm{b}}$ & $2.459^{\mathrm{b}}$ \\
3 Months & $3.672^{\mathrm{c}}$ & $2.773^{\mathrm{c}}$ \\
LSD at 0.05 & 0.018 & 0.143 \\
P value & 0.0000 & 0.0013 \\
\hline
\end{tabular}

* Each figure is a mean of 3 samples

Figures in the same column with the same superscript letter are not significantly different while those with different subscripts are significantly different at 5\%. 


\section{Table 3}

Mean scores for the different sensory attributes of the fortified and non-fortified bean sauces

\begin{tabular}{llll}
\hline & Colour & Flavour & Overall acceptability \\
\hline Fortified & 2.100 & 2.533 & 2.333 \\
Not Fortified & 5.367 & 3.300 & 4.667 \\
LSD at 0.05 & 1.147 & 0.517 & 0.799 \\
P value & 0.0066 & 0.0237 & 0.0063 \\
\hline
\end{tabular}

Results are a mean of 19 panellists.

Scores are based on a 9 point hedonic scale (1 like extremely, 5 neither like nor dislike and 9 dislike extremely. 


\section{Table 4}

Some Iron-rich foods and their Iron content

\begin{tabular}{ll}
\hline Food Item & Iron Concentration $(\mathrm{mg} / 100 \mathrm{~g})$ \\
\hline Blood powder & $195.46^{*}$ \\
Boiled liver & 17.0 \\
Boiled Kidney & 12.0 \\
Fish & 4.6 \\
Beef & 3.5 \\
Mutton & 2.1 \\
Eggs & 1.9
\end{tabular}

Source: McCance and Widdowson's "The composition of foods" [20]

* Value from chemical analysis in the present study 


\section{REFERENCES}

1. FAO (Food and Agriculture of the United Nations) and ILSI (International Life Sciences Institute). Preventing micronutrient malnutrition; a guide to food-based approaches. ILSI Press, Washington, DC, 1997

2. Gillespie S, Kevany $\mathbf{J}$ and $\mathbf{J}$ Mason Controlling iron deficiency. Nutrition Policy Research paper No. 9. ACC/SCN, WHO, Geneva, 1991

3. Ruel MT Can food-based strategies help reduce vitamin A and iron deficiencies; $A$ review of recent evidence. IFPRI, Washington, DC, 2001

4. Sifri Z, Darnton-Hill I, Baker SK, Ag Bendech M and VM Aguayo A concise overview w of micronutrient deficiencies in Africa and future directions. Afr. J. Food Nutr. Sc. 2004; 2(2):78-85

5. Zhengxing $\mathbf{C}$ and $\mathbf{W}$ Oldewage-Theron Food fortification to prevent and control iron deficiency. Afr. J. Food Nutr. Sc. 2002; 2(2):67-77

6. Hulthen L Iron deficiency and cognition. Scand. J. Nutr. 2003; 47(3):152-156

7. Byaruhanga $\mathbf{J}$ An annotated bibliography of anaemia in Uganda. Ministry of Health, Kampala. The Republic of Uganda, 2001

8. UDHS (Uganda Demographic and Health Survey) Uganda Bureau of Statistics, Entebbe and ORC Macro, Calverton, Maryland, USA, 2000-2001

9. Campbell JR and JF Lasley The science of animals that serve mankind. McGraw-Hill Book Company, New York, London, 1969

10. Swatland HJ Structure and development of meat animals. $2^{\text {nd }}$ edn. Prentice-Hall-Inc, New Jersey, USA, 1984

11. Sinclair AM and G Howat World nutrition and nutrition education, 2nd edn. Oxford, UNESCO Publication, London, UK, 1980

12. Yeudall F, Gibson RS, Kayira $\mathbf{C}$ and $\mathbf{E}$ Umar Efficacy of a multi-micronutrient dietary intervention based on haemoglobin, hair zinc concentrations, and selected functional outcomes in rural Malawian children. Eur. J. Clin. Nutr. 2002; 56(12):1176-85

13. AOAC, Official Methods of Analysis $16^{\text {th }}$ edn. AOAC International, Gaithersburg, Maryland, USA, 1997 
14. Swanson KMJ, Busta FF, Peterson EH and G Johnson Colony counts methods. In: C Vanderzant and DF Splittstosser (Eds). Compendium of Methods of Microbiological Examination of Foods. 3rd edn. American Public Health Association, Washington DC, 1992: 75-95

15. Mislivec PB, Beuchat LR and MA Cousin Yeasts and moulds In: C Vanderzant and DF Splittstosser (Eds). Compendium of Methods of Microbiological Examination of Foods. 3rd edn. American Public Health Association, Washington DC, 1992: 239-249

16. Gisela J Sensory evaluation of food; theory \& practice, 2nd edn. Ellis Horword Series in Food Science \& Technology, Chichester, England, 1990.

17. Fennema O Food Chemistry, $4^{\text {th }}$ Edition; Marcel Dekker, Inc.; New York and Basel. 1995: $118-1015$

18. Pomeranz Y and EM Clifton Food analysis theory and practice, 3rd edn. Chapman \& Hall, New York USA. 1994: 575-588

19. Pond WG, Church DC and KR Pond Basic animal nutrition and feeding, 4 edn. John Wiley \& Sons, New York, USA. 1995: 190-196

20. Holland B and AA Welch Unwin ID, Bus DH, Paul AA and Southgate DAT, McCance and Widdowson's The composition of foods. 5th edn. The Royal Society of Chemistry and Ministry of Agriculture, Fisheries and Food, UK. Royal Society of Chemistry Publication, UK, 1993

21. Dietary reference values for energy and nutrients for the United Kingdom Report of the Panel of Dietary Reference Values of the Committee on Medical Aspects of Food Policy. Department of Health, Report on Health and Social Subjects. HMSO, London, 1991

22. FAO/WHO. Expert committee on food additives and contaminants. FAO, Rome, 2003

23. Conrad ME, Benjamin BI, Williams SHL and AL Foy Human absorption of hemoglobin iron. J. Gastro Ent. 1997; 53:5-10

24. Walter T, Hertrampf $\mathbf{E}$ and $\mathbf{F}$ Pizzaro Effect of bovine-haemoglobin-fortified cookies on iron status of school children: nationwide program in Chile. Am. J. Clin. Nutr. 1993; 57:190-194

25. Hertrampf E, Olivares $M$ and F Pizarro Haemoglobin fortified cereal: a source of available iron in breast fed infants. Eur. J. Clin. Nutr. 1990; 44:793-798 